\title{
EVALUASI STATUS KEBUGARAN JASMANI DAN TINGKAT PENGUASAAN KETERAMPILAN OLAHRAGA SEPAKBOLA DAN BOLA VOLI MAHASISWA PJKR SEMESTER V STKIP CITRA BAKTI NGADA BERDASARKAN AKTIVITAS PERKULIAHAN PRAKTEK DAN PEMBINAAN KEGIATAN UKM
}

\author{
Yohanes Bayo Ola Tapo \\ Dosen PJKR STKIP Citra Bakti \\ email: yoh.ola.tapo@gmail.com
}

\begin{abstract}
Abstrak
Penelitian ini merupakan penelitian kualitatif menggunakan pendekatan jenis penelitian deskriptif kuantitatif dengan teknik tes dan pengukuran untuk mengevaluasi status kebugaran jasmani dan tingkat penguasaan keterampilan olahraga berdasarkan keterlibatan mahasiswa pada perkuliahan praktek dan pembinaan kegiatan UKM sepakbola dan bola voli. Sampel dalam penelitian ini adalah mahasiswa PJKR semester $\mathrm{V}$ yang memenuhi kriteria yang ditetapkan oleh peneliti yang berjumlah 20 orang. Instrumen dalam penelitian ini menggunakan Tes Kesegaran Jasmani Indonesia (TKJI), tes keterampilan sepakbola menurut STO Bandung dan tes keterampilan bola voli menurut AAHPERD Volleyball Test. Hasil tes dan pengukuran dianalisis menggunakan teknik analisis deskriptif kuantitatif, dan diperoleh simpulan penelitian bahwa: secara keseluruhan status tingkat kesegaran jasmani dan penguasaan keterampilan kecabangan olahraga mahasiswa PJKR semester V berada pada kategori "SEDANG", sehingga pelaksanaan kegiatan perkuliahan praktek dan pembinaan kegiatan UKM keolahragaan harus benar-benar ditingkatkan dengan pendampingan yang lebih serius, displin dan terprogram secara baik dari para dosen PJKR dengan kemasan berbagai model, formasi, serta strategi pembelajaran dan latihan untuk meningkatkan status kesegaran jasmani dan keterampilan kecabangan olahraga sebagai salah satu kompetensi dasar yang diperlukan mahasiswa PJKR.
\end{abstract}

Kata Kunci: Evaluasi, Statatus Kebugaran Jasmani, Keterampilan Kecabangan Olahraga Sepak Bola dan Bola Voli.

\begin{abstract}
This research is a qualitative research using quantitative descriptive research type approach with test and measurement techniques to evaluate the level of physical fitness and sports skills mastery of the student who are involved in practical lectures and Student Activities Unit (Unit Kegiatan Mahasiswa) soccer and volleyball. The sample in this study was of the $5^{\text {th }}$ semester PJKR students, STKIP Citra Bakti, who met the criteria set by the researcher, amounting to 20 students. The instruments used in this research were the Tes Kesegaran Jasmani Indonesia (TKJI), soccer skills tests by STO Bandung and volleyball skills tests by AAHPERD Volleyball Test. The results of the tests and measurements were analyzed using quantitative descriptive analysis techniques. Overall, the level of physical fitness and sports skills mastery of the $5^{\text {th }}$ semester of PJKR students, STKIP Citra Bakti were in the category "MEDIUM", so the implementation of practical lectures and Student Activities Unit should improved more serious, disciplined and well programmed by PJKR lecturers using various models, formations of learning and training strategies to improve the level physical fitness and sports skills as the basic competencies of the PJKR students.
\end{abstract}

Keywords: Evaluation, Physical Fitness Status, Soccer and Volleyball Sports Skills. 


\section{PENDAHULUAN}

Program Studi Pendidikan Jasmani Kesehatan dan Rekreasi (PJKR) merupakan salah satu program studi di STKIP Citra Bakti Ngada, yang berproses dan berperan dengan visi: "Terwujudnya Program Studi PJKR yang Unggul dan Inovatif dalam Menghasilkan Lulusan yang Beriman, Berkarakter, Berkompeten dan Bertaraf Nasional di Tahun 2023" dengan salah satu visi yang diemban adalah: "Mengembangkan dan Melahirkan SDM Lulusan yang Terampil dan inovatif serta memiliki kompetensi sebagai pendidik yang unggul serta siap kerja melalui penyelenggaraan pendidikan yang berkualitas". Pencapaian cita-cita mulia ini tentu bukan merupakan sesuatu yang mudah, sehingga segala daya, upaya dan usaha yang serius dan berkesinambungan dari berbagai unsur penunjang menjadi salah satu keharusan yang mutlak dilakukan. Program studi PJKR sendiri sudah seharusnya dan sudah sewajibnya dapat memanfaatkan dan mengembangkan segala unsur penunjang keberhasilan dalam mewujudkan harapan dan cita-cita ini dengan berbagai langkah nyata terutama pada layanan akademik dan non akademik mahasiswa.
Program studi PJKR telah melakukan berbagai upaya nyata dalam memberikan layanan pendidikan kepada mahasiswa mulai dari kegiatan akademik seperti perkuliahan yang selalu ditingkatkan lewat usaha pengembangan kurikulum perkuliahan yang disusun guna menjawabi tuntutan dunia kerja dalam bidang keolahragaan baik sebagai guru, pelatih maupun pendamping olahraga, serta kegiatan non akademik dalam bidang pembinaan kecabangan olahraga yang diselenggarakan secara rutin melalui Unit Kegiatan Mahasiswa (UKM) sebagai salah satu kegiatan wajib program studi PJKR yang telah dilaksanakan dengan cara dan upaya yang jelas, walaupun masih banyak kekurangan-kurangan yang belum dapat diusahakan oleh program studi karena berbagai hal mendasar.

Langkah kongkrit yang harus dicapai sebagai langkah awal dalam membenahi kekurangankekurangan ini dapat ditempuh melalui kegiatan evaluasi pada berbagai aspek penyelenggaraan pendidikan guna memperoleh data yang real dan lengkap tentang seberapa besar pencapaian yang telah diperoleh dari berbagai upaya yang telah dilakukan. Hal ini dilakukan mengingat evaluasi merupakan suatu kegiatan atau 
upaya yang perlu dilakukan untuk mengukur dan membandingkan hasil atau dampak suatu aktivitas, program, atau proyek yang dilakukan dengan tujuan yg telah ditetapkan, dan bagaimana cara pencapaiannya.

Kegiatan evaluasi yang dilakukan program studi PJKR sejauh ini masih dilakukan secara akademik melalui kegiatan Ujian Tengah Semester (UTS) dan Ujian Akhir Semester (UAS), menggunakan indikator penilaian yang hanya berpedoman pada materi perkuliahan, sedangkan evaluasi pembinaan pada kegiatan pendampingan UKM terutama pada kecabagan olahraga belum pernah dilakukan. Hal ini kemudian menjadikan program studi tidak memiliki data yang cukup real dan lengkap tentang kemampuan dan kompetensi mahasiswa, terutama pada kecabangan olahraga mulai dari status kebugaran jasmani maupun tingkat penguasaan keterampilan kecabangan olahraga yang menjadi dua hal mendasar yang cukup penting dimiliki oleh mahasiswa program studi PJKR.

Keadaan pada program studi PJKR sepeti yang telah diuraikan, memberikan arahan yang cukup jelas bahwa sangat diperlukan kegiatan evaluasi yang cukup mendalam guna mengevaluasi sejauh mana usaha yang telah dilaksanakan pada proses

$\begin{array}{lrr}\text { perkuliahan } & \text { praktek } & \text { dan } \\ \text { pembinaan } & \text { kegiatan } & \text { UKM } \\ \text { memberikan } & \text { dampak } & \text { pada }\end{array}$
kemampuan dan kompetensi mahasiswa, baik dari segi status kebugaran jasmani maupun tingkat penguasaan keterampilan kecabangan olahraga sebagai langkah awal yang baik bagi program studi PJKR untuk mengembangkan layanan pendidikan yang lebih optimal. Kegitan evaluasi yang dimaksud akan lebih maksimal dan mendalam jika melalui sebuah kegiatan penelitian evaluasi yang dilaksanakan dengan sebuah prosedur ilmiah secara sistematis. Hal ini sejalan dengan pendapat Arikunto, S. (2007: 222) yang menjelaskan bahwa penelitian evaluasi merupakan suatu proses yang dilakukan dalam rangka menentukan kebijakan dengan terlebih dahulu mempertimbangkan nilai-nilai positif dan keuntungan suatu program, serta mempertimbangkan proses serta teknik yang telah digunakan dalam melakukan penelitian.

Kegiatan evaluasi status kebugaran jasmani yang dilakukan bermaksud untuk mengevaluasi sejauhmana proses perkuliahan praktek yang telah dilaksanakan berdampak pada status kebugaran jasmani mahasiswa PJKR yang aktif mengikuti segala bentuk kegiatan perkuliahan praktek, hal 


\begin{tabular}{|c|c|}
\hline 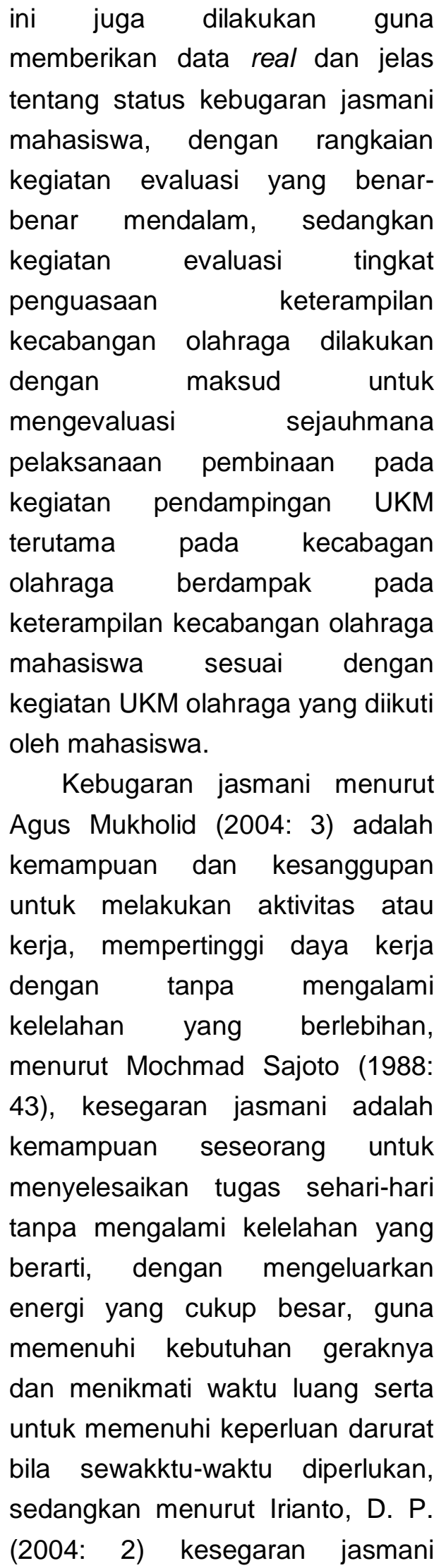 & 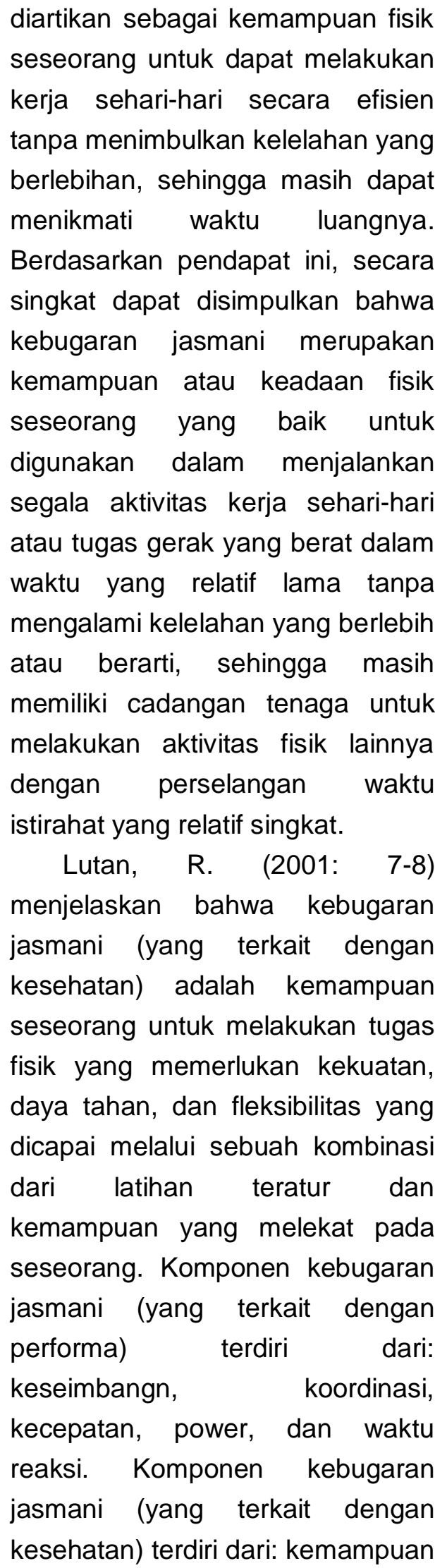 \\
\hline
\end{tabular}


aerobik, kekuatan otot, daya tahan otot, fleksibilitas, dan komposisi tubuh yang terkait dengan peningkatan kesehatan.

\section{Suharjana}

(2013:

menjelaskan bahawa: komponen kebugaran jasmani menjadi dua kelompok, yaitu: 1). Kebugaran jasmani yang berhubungan dengan kesehatan, meliputi: daya tahan paru dan jantung, kekuatan otot, daya tahan otot, fleksibilitas, komposisi tubuh, dan 2). Kebugaran jasmani yang berhubungan dengan keterampilan, meliputi: kecepatan, daya ledak, keseimbangan, kelincahan, koordinasi.

Berdasarkan penjelasan kedua ahli ini, dapat dilihat bahwa di dalam kebugaran jasmani terdapat komponen-komponen dari kesegaran jasmani yang terdiri dari: daya tahan paru dan jantung, kekuatan otot, daya tahan otot, fleksibilitas, kecepatan, daya ledak, keseimbangan, kelincahan, dan koordinasi. Komponen kebugaran jasmani ini, kemudian dapat diklasifikasikan menjadi dua komponen besar kebugaran jasmani, yaitu: (1) Komponen kebugaran jasmani yang berhubungan dengan kesehatan yang ditujukan kepada siapa saja, meliputi: kemampuan aerobik yang terdiri dari kemampuan daya tahan paru dan jantung, kekuatan otot, daya tahan otot, fleksibilitas, dan komposisi tubuh yang terkait dengan kesehatan, dan (2) Komponen kebugaran jasmani yang berhubungan dengan performa atau keterampilan yang ditujukan lebih kepada para atlet, meliputi: keseimbangan, daya ledak (power), kecepatan, waktu reaksi, koordinasi dan kelincahan.

Status kebugaran jasmani seperti yang telah di uraikan dapat diukur dan di evalauasi menggunakan tes dan pengukuran kebugaran jasmani yang dikembangkan sebagai upaya untuk menilai dan mengevaluasi berbagai status komponen dari kebugaran jasmani. Tes dan pengukuran kebugaran jasmani salah satunya dapat menggukan baterry test kebugaran jasmani "Tes Kebugaran Jasmani Indonesia (TKJI)" yang terdiri dari lima item tes dan pengukuran komponen kebugaran jasmani, yaitu: Kecepatan, Kekuatan Otot Tangan, Kekuatan Otot Perut, Daya Ledak Otot Tungkai dan Daya Tahan Aerobik. Tes Kesegaran Jasmani Indonesia (TKJI) yang disusun dalam lokakarya kesegaran jasmani pada tahun 1984 yang disusun dalam buku "Tes Kesegaran Jasmani Indonesia", terdiri dari 4 kelompok usia, yaitu : 6-9 tahun, 10-12 tahun, 13-15 tahun, dan 16-19 tahun yang masing-masing kelompok usia memiliki ketentun tes masing- 
masing (Depdikbud: 1999). Tes

TKJI telah disepakati dan ditetapkan menjadi instrumen atau alat tes yang berlaku di seluruh wilayah Indonesia karena TKJI disusun dan disesuaikan dengan kondisi anak Indonesia. Pelaksanaan tes TKJI dilaksanakan dengan Rangkaian Tes yang terdiri dari butir-butir tes yang disesuaikan dengan jenis kelamin peserta tes, yaitu.

a. Rangkaian Tes TKJI untuk Putra, terdiri dari lima item tes, yaitu: lari 60 meter, bergantung angkat tubuh (pull up) selama 60 detik, baring duduk (sit up) selama 60 detik, loncat tegak (vertical jump), dan lari 1200 meter.

b. Rangkaian Tes TKJI untuk Putri, terdiri dari lima item tes, yaitu: lari 50 meter, bergantung siku tekuk ( $p u l l$ up) selama 60 detik, baring duduk (sit up) selama 60 detik, loncat tegak (vertical jump), dan lari 1000 meter.

TKJI merupakan tes dan pengukuran dalam bentuk baterry test sehingga dilakukan secara berurutan dan tanpa jeda untuk setiap peserta, kemudian hasil setiap buir tes dalam bentuk nilai kasar dengan satuan yang berbeda-beda, terlebih dahulu diubah menjadi satuan yang sama, yaitu "NILAI" sesuai dengan kriteria masing-masing butir tes khusus untuk kategori umur 16-19 tahun, seperti pada Tabel 01 dan Tabel 02 berikut.

Tabel 01. Nilai Tes Kesegaran Jasmani Indonesia (TKJI) Untuk Putra Usia 16-19 Tahun

\begin{tabular}{|c|c|c|c|c|c|}
\hline \multirow{2}{*}{$\begin{array}{c}\text { Kategori } \\
\text { Nilai }\end{array}$} & $\begin{array}{c}\text { Lari } \\
\mathbf{6 0} \mathbf{m} \\
(\text { detik) }\end{array}$ & $\begin{array}{c}\text { Gantung } \\
\text { Angkat } \\
\text { Tubuh } \\
\text { (kali) }\end{array}$ & $\begin{array}{c}\text { Baring } \\
\text { Duduk } \\
\text { (kali) }\end{array}$ & $\begin{array}{c}\text { Loncat } \\
\text { Tegak } \\
(\mathrm{cm})\end{array}$ & $\begin{array}{c}\text { Lari } \\
\mathbf{1 2 0 0} \mathbf{m} \\
\text { (menit'detik) }\end{array}$ \\
\hline $\mathbf{5}$ & $<7,2$ & $>19$ & $>41$ & $>73$ & $<3$ '14 \\
\hline $\mathbf{4}$ & $7.3-8,3$ & $14-18$ & $30-40$ & $60-72$ & $3^{\prime} 15-4{ }^{\prime} 25$ \\
\hline $\mathbf{3}$ & $8,4-9,6$ & $9-13$ & $21-29$ & $50-59$ & 4 '26-5'12 \\
\hline $\mathbf{2}$ & $9,7-11,0$ & $5-8$ & $10-20$ & $39-49$ & $5^{\prime} 13-6$ '33 \\
\hline $\mathbf{1}$ & $>11,1$ & $0-4$ & $0-9$ & $<38$ & $>6$ '34 \\
\hline
\end{tabular}

Tabel 02. Nilai Tes Kesegaran Jasmani Indonesia (TKJI) Untuk Putri Usia 16-19 Tahun

\begin{tabular}{|c|c|c|c|c|c|}
\hline \multirow{2}{*}{$\begin{array}{c}\text { Kategori } \\
\text { Nilai }\end{array}$} & \multicolumn{5}{|c|}{ Item Tes TKJI } \\
\cline { 2 - 6 } & $\begin{array}{c}\text { Lari } \\
\text { (detik) }\end{array}$ & $\begin{array}{c}\text { Gantung } \\
\text { Siku } \\
\text { Tekuk }\end{array}$ & $\begin{array}{c}\text { Baring } \\
\text { Duduk } \\
\text { (kali) }\end{array}$ & $\begin{array}{c}\text { Loncat } \\
\text { Tegak } \\
\text { (cm) }\end{array}$ & $\begin{array}{c}\text { Lari } \\
1000 \mathrm{~m} \\
\text { (detik) }\end{array}$ \\
\hline
\end{tabular}




\begin{tabular}{|c|c|c|c|c|c|}
\hline & & $($ detik) & & & \\
\hline $\mathbf{5}$ & $<8,4$ & $>40$ & $>29$ & $>50$ & $<3^{\prime} 52^{\prime \prime}$ \\
\hline $\mathbf{4}$ & $8,5-9,8$ & $20-39$ & $20-28$ & $39-49$ & $3^{\prime} 53-4{ }^{\prime} 56$ \\
\hline $\mathbf{3}$ & $9,9-11,4$ & $08-19$ & $10-19$ & $31-38$ & $4^{\prime} 57-5^{\prime} 58$ \\
\hline $\mathbf{2}$ & $11,5-13,4$ & $02-07$ & $03-09$ & $23-30$ & $5 ' 59-7^{\prime} 23$ \\
\hline $\mathbf{1}$ & $>13.5$ & $00-02$ & $00-02$ & $<23 \mathrm{~cm}$ & $>7$ '23 \\
\hline
\end{tabular}

Nilai setiap buir tes yang telah diubah menjadi satuan yang sama, yaitu "NILAl" sesuai dengan kriteria masing-masing butir tes, kemudian dijumlahkan dan disesuaikan dengan norma TKJI kategori umur 16-19 tahun baik untuk putra dan putri seperti pada Tabel 03 berikut.

Tabel 03. Norma Tes Kesegaran Jasmani Indonesia (TKJI)

\begin{tabular}{|c|c|c|c|}
\hline No & $\begin{array}{c}\text { Jumlah Nilai Lima Item } \\
\text { Tes }\end{array}$ & \multicolumn{2}{|c|}{$\begin{array}{c}\text { Klasifikasi Kesegaran } \\
\text { Jasmani }\end{array}$} \\
\hline $\mathbf{5}$ & $22-25$ & Baik Sekali & BS \\
\hline $\mathbf{4}$ & $18-21$ & Baik & B \\
\hline $\mathbf{3}$ & $14-17$ & Sedang & S \\
\hline $\mathbf{2}$ & $10-13$ & Kurang & K \\
\hline $\mathbf{1}$ & $5-9$ & Kurang Sekali & KS \\
\hline
\end{tabular}

Keterampilan kecabangan olahraga sepakbola dapat dinilai dan dievaluasi dari berbagai keterampilan teknik dasar sepakbola menggunakan bettery test keterampilan bermain sepakbola yang dikembangkan oleh STO Bandung pada tahun 1971 seperti yang dikutip kembali oleh Winarno (2006: 44-64), dengan validitas tes 0,65 dan reliabilitas tes 0,77 .

Bettery test keterampilan bermain sepakbola yang dikembangkan oleh STO Bandung dilaksanakan dalam satu rangkaian tes, yang terdiri dari empat item tes, yaitu: tes heading, passingstopping, dribbling, dan shooting, yang secara khusus digunakan untuk mengukur dan menentukan tingkat keterampilan bermain sepakbola dengan mengevaluasi keterampilan beberapa teknik dasar dalam permainan sepakbola. Hasil tes masing-masing butir tes berupa nilai kasar terlebih dulu diubah menjadi skor standar "NilaiT" dan kemudian nilai T dari setiap hasil dijumlahkan dan dibagi 5 . Nilai hasil bagi tersebut adalah nilai keterampilan bermain sepakbola yang selanjutnya dibandingkan dengan tabel norma tingkat keterampilannya bermain sepakbola seperti pada Tabel 04 berikut. 
Tabel. 04. Norma Penggolongan Keterampilan Bermain Sepakbola STO Bandung

(Winarno, 2006: 64)

\begin{tabular}{|c|ll|c|}
\hline Nilai Keterampilan & \multicolumn{2}{|c|}{ Golongan } & Nilai Keterampilan \\
\hline $61-$ ke atas & Baik & (B) & $61-$ ke atas \\
\hline $53-60$ & Cukup & (C) & $53-60$ \\
\hline $46-52$ & Sedang & (S) & $46-52$ \\
\hline $37-45$ & Kurang & (K) & $37-45$ \\
\hline$\leq-36$ & Kurang Sekali & (KS) & $\leq-36$ \\
\hline
\end{tabular}

Keterampilan kecabangan olahraga bola voli dapat dinilai dan dievaluasi dari berbagai keterampilan teknik dasar bola voli menggunakan bettery test keterampilan bermain bola voli menurut American Association for Health, Physical Education Recreation and Dance (AAHPERD) seperti yang dikutip kembali oleh Winarno (2006: 27-43) dengan validitas isi tes tidak kurang dari 0,80 dan koefisien reliabilitas tes tidak kurang dari 0,70.

Bettery test keterampilan bermain bola voli menurut American Association for Health, Physical Education Recreation and Dance (AAHPERD) dilaksanakan dalam satu rangkaian tes, yang terdiri dari empat item tes, yaitu: tes memvoli (vollying), service, passing, dan mengumpan (set-up) yang secara khusus digunakan untuk mengukur dan menentukan tingkat keterampilan bermain bola voli dengan mengevaluasi keterampilan beberapa teknikteknik dasar dalam permainan bola voli. Hasil tes masing-masing butir tes berupa nilai kasar terlebih dulu diubah menjadi skor standar yang disesuaikan dengan tabel AAHPERD Volleyball Test Norms dengan Percentile Scores Based on Age pada masing-masing item tes (Winarno, 2006: 39-42), kemudian nilai konfersi yang diperoleh dijumlahkan dan dibagi 4 . Nilai hasil bagi tersebut adalah nilai keterampilan bermain bola voli yang selanjutnya dibandingkan dengan tabel norma tingkat keterampilan bermain bola voli, menggunakan perhitungan pengkategorian skala teoritik dengan rumus perhitungan seperti pada tabel 05.

Tabel 05. Perhitungan Pengkategorian/Klasifikasi dengan Perhitungan Skala Lima Teoritik.

\begin{tabular}{|c|c|}
\hline Rentang Skor & \multicolumn{2}{|c|}{ Klasifikasi } \\
\hline $\mathrm{Mi}+1,5 \mathrm{SDi}-<\mathrm{Mi}+3,0 \mathrm{SDi}$ & Baik \\
\hline
\end{tabular}




\begin{tabular}{|l|ll|}
\hline $\mathrm{Mi}+0,5 \mathrm{SDi}-<\mathrm{Mi}+1,5 \mathrm{SDi}$ & Cukup & (C) \\
\hline $\mathrm{Mi}-0,5 \mathrm{SDi}-<\mathrm{Mi}+0,5 \mathrm{SDi}$ & Sedang & (S) \\
\hline $\mathrm{Mi}-1,5 \mathrm{SDi}-<\mathrm{Mi}-0,5 \mathrm{SDi}$ & Kurang & (K) \\
\hline $\mathrm{Mi}-3,0 \mathrm{SDi}-<\mathrm{Mi}-1,5 \mathrm{SDi}$ & Kurang Sekali & (KS) \\
\hline
\end{tabular}

Perhitungan pengkategorian atau klasifikasi dengan perhitungan skala lima teoritik berdasarkan Standar Penilaian AAHPERD Volleyball Test Norms (Winarno, 2006: 39-42), maka norma tes yang digunakan untuk menilai penggolongan keterampilan bermaian bola voli seperti pada Tabel 06.

\section{Tabel. 06. Norma Penggolongan Keterampilan Bermain Bola Voli}

(Dikembangkan Peneliti Berdasarkan Standar Penilaian

AAHPERD Volleyball Test Norms dalam Winarno, 2006: 39-42)

\begin{tabular}{|c|ll|c|}
\hline Nilai Keterampilan & \multicolumn{2}{|c|}{ Golongan } & Nilai Keterampilan \\
\hline $75-100$ & Baik & (B) & $75-100$ \\
\hline $58-<75$ & Cukup & (C) & $58-<75$ \\
\hline $42-<58$ & Sedang & (S) & $42-<58$ \\
\hline $25-<42$ & Kurang & (K) & $25-<42$ \\
\hline $0-<25$ & Kurang Sekali & (KS) & $0-<25$ \\
\hline
\end{tabular}

\section{Metode Penelitian}

Pendekatan yang digunakan dalam penelitian ini adalah pendekatan kuantitatif dalam bentuk penelitian deskriptif, sehingga jenis penelitian ini merupakan penelitian deskriptif kuantitatif menggunakan teknik tes dan pengukuran untuk mengetahui status kebugaran jasmani dan tingkat penguasaan keterampilan kecabangan olahraga (sepakbola dan bola voli) mahasiswa PJKR semester V STKIP Citra Bakti berdasarkan keterlibatan mahasiswa pada kegiatan perkuliahan dan kegiatan UKM sepakbola dan bola voli sesuai pilihan masing-masing. Populasi dan sampel dalam penelitian ini adalah seluruh mahasiswa PJKR semester $V$ STKIP Citra Bakti Ngada yang memenuhi kriteria sebagai berikut: (1) Mahasiswa PJKR semester $V$ yang tetap aktif mengikuti perkuliahan dari semester I sampai dengan semester $V$ tanpa pernah mengambil cuti dengan alasan apapun, (2) Mahasiswa PJKR semester $V$ yang terdaftar dan aktif mengikuti kegiatan UKM sepakbola dan bola voli, dan (3) Mahasiswa PJKR semester $V$ yang tidak sedang menjalankan latihan khusus persiapan mengikuti 
kejuaraan sepakbola dan bola voli dalam kurun waktu 2-3 bulan saat penelitian dilaksanakan, sehingga secara umum jumlah sampel dalam penelitian ini adalah 20 orang mahasiswa. Penelitian dilaksanakan dari bulan Juli sampai bulan Desember 2018. Metode pengumpulan data dalam penelitian ini menggunakan tes dan pengukuran, yang terdiri dari: (1) tes dan pengukuran status kebugaran jasmani menggunakan instrumen Tes Kesegaran Jasmani Indonesia (TKJI), (2) tes dan pengukuran tingkat penguasaan keterampilan kecabangan olahraga sepakbola menggunakan instrumen tes keterampilan sepakbola yang dikembangkan oleh STO Bandung, dan (3) tes dan pengukuran tingkat penguasaan keterampilan kecabangan olahraga bola voli menggunakan Bettery test keterampilan bermain bola voli menurut American Association for Health, Physical Education Recreation and Dance (AAHPERD).

$\begin{array}{cc}\text { Selain kedua } & \text { metode } \\ \text { penelitian } & \text { tersebut, dalam }\end{array}$
pengumpulan data penelitian ini juga menggunakan metode dokumentasi (pemberkasan) untuk mengumpulkan berbagai data pendukung penelitian, yang meliputi: (1). Data sampel penelitian sesuai dengan kriteria sampel penelitian, yaitu: daftar mahasiswa PJKR angkatan $\mathrm{V}$ yang berada pada semester $\mathrm{V}$ tanpa pernah mengambil cuti dengan alasan apapun, terdaftar dan aktif mengikuti kegiatan UKM sepakbola dan bola voli, dan tidak sedang menjalankan latihan khusus persiapan mengikuti kejuaraan sepakbola dan bola voli dalam kurun waktu 2-3 bulan saat penelitian dilaksanakan, dan (2). Data-data perkuliahan praktek Prodi PJKR (kurikulum, jadwal perkuliahan, abensi mahasiswa, dan berita acara dosen), data kegiatan UKM sepakbola dan UKM bola voli (jadwal kegiatan, absensi mahasiswa, jadwal dan model pembinaan UKM).

Semua data penelitian yang terkumpul, kumudian dianalisis menggunakan teknik analisis deskriptif kuantitatif yang dilakukan dengan beberapa tahap analisis data, yaitu terdiri dari: Pengorganisasian Data (Reduksi Data); Semua data penelitian akan direduksi untuk mengumpulkan data hasil penelitian, sehingga data dirangkum dan difokuskan pada hal-hal penting yang berkaitan langsung dengan permasalahan penelitian agar tidak salah menggunakan data-data yang tidak ada kaitan dengan tujuan penelitian. (2) Pengkategorian Data (Display Data); Setelah data dikumpulkan dan direduksi 


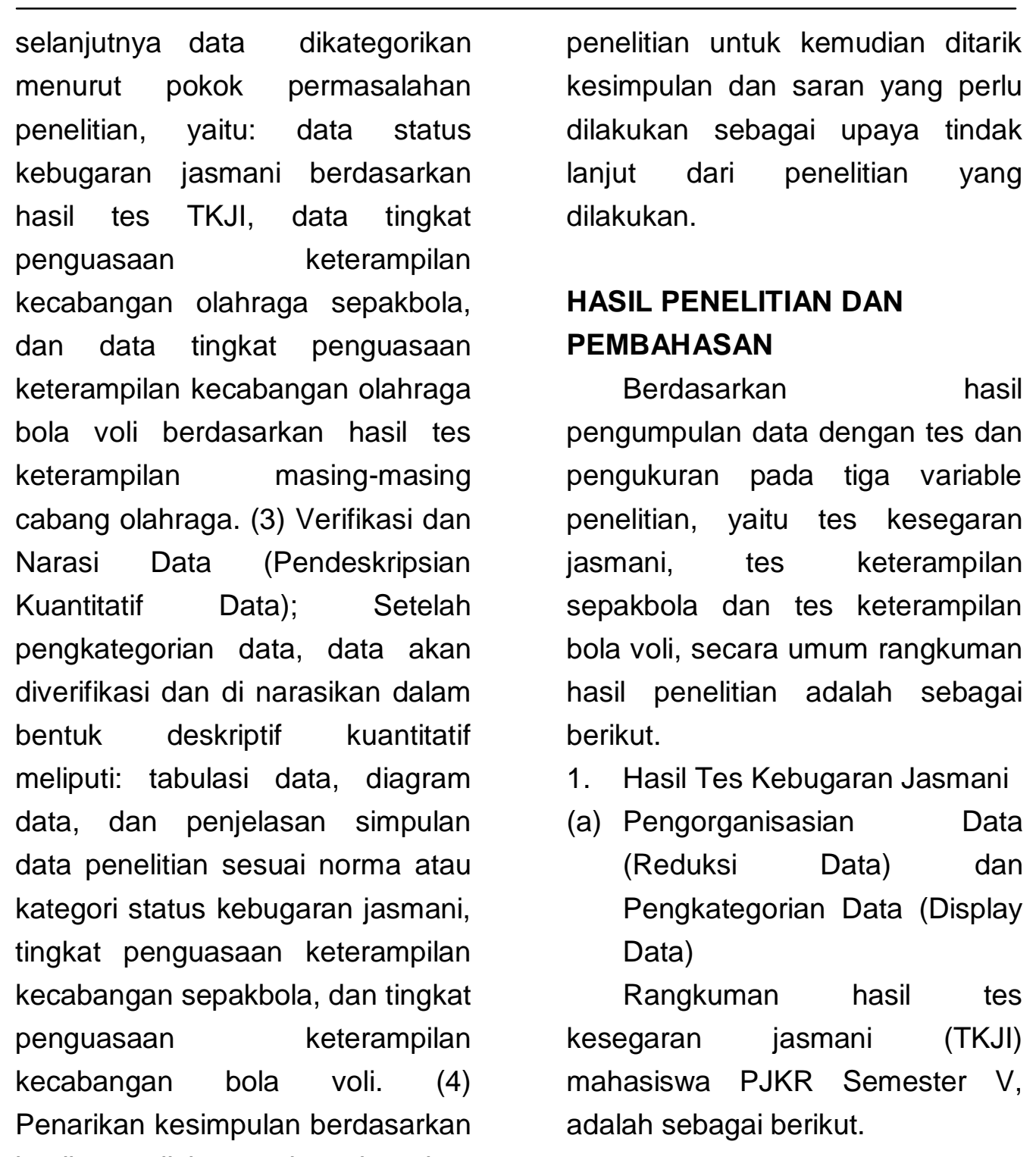

hasil analisis pada data-data

Tabel 07. Rangkuman Hasil Tes Kesegaran Jasmani (TKJI) Mahasiswa

\section{Putra}

\begin{tabular}{|c|c|c|c|c|c|}
\hline \multirow{2}{*}{$\begin{array}{c}\text { Kategori } \\
\text { Nilai }\end{array}$} & \multicolumn{5}{|c|}{$\begin{array}{c}\text { Item Tes TKJI } \\
\text { (Jumlah Sampel) }\end{array}$} \\
\cline { 2 - 6 } & $\begin{array}{c}\text { Lari } \\
\mathbf{5 0 ~} \mathbf{~ m} \\
\text { (orang) }\end{array}$ & $\begin{array}{c}\text { Gantung } \\
\text { Siku Tekuk } \\
\text { (orang) }\end{array}$ & $\begin{array}{c}\text { Baring } \\
\text { Duduk } \\
\text { (orang) }\end{array}$ & $\begin{array}{c}\text { Loncat } \\
\text { Tegak } \\
\text { (orang) }\end{array}$ & $\begin{array}{c}\text { Lari } \\
\mathbf{1 0 0 0} \mathbf{~ m} \\
\text { (orang) }\end{array}$ \\
\hline $\mathbf{5}$ & 2 & 3 & 4 & 0 & 0 \\
\hline $\mathbf{4}$ & 2 & 6 & 7 & 2 & 0 \\
\hline $\mathbf{3}$ & 9 & 4 & 2 & 7 & 2 \\
\hline $\mathbf{2}$ & 0 & 0 & 0 & 2 & 8 \\
\hline $\mathbf{1}$ & 0 & 0 & 0 & 2 & 3 \\
\hline JML & $\mathbf{1 3}$ & $\mathbf{1 3}$ & $\mathbf{1 3}$ & $\mathbf{1 3}$ & $\mathbf{1 3}$ \\
\hline
\end{tabular}


Tabel 08. Rangkuman Hasil Tes Kesegaran Jasmani (TKJI) Mahasiswa Putri

\begin{tabular}{|c|c|c|c|c|c|}
\hline \multirow{2}{*}{$\begin{array}{c}\text { Kategori } \\
\text { Nilai }\end{array}$} & \multicolumn{5}{|c|}{$\begin{array}{c}\text { Item Tes TKJI } \\
\text { (Jumlah Sampel) }\end{array}$} \\
\cline { 2 - 6 } & $\begin{array}{c}\text { Lari } \\
\mathbf{5 0 ~} \mathbf{m} \\
\text { (orang) }\end{array}$ & $\begin{array}{c}\text { Gantung } \\
\text { Siku Tekuk } \\
\text { (orang) }\end{array}$ & $\begin{array}{c}\text { Baring } \\
\text { Duduk } \\
\text { (orang) }\end{array}$ & $\begin{array}{c}\text { Loncat } \\
\text { Tegak } \\
\text { (orang) }\end{array}$ & $\begin{array}{c}\text { Lari } \\
\mathbf{1 0 0 0} \mathbf{~ m} \\
\text { (orang) }\end{array}$ \\
\hline $\mathbf{5}$ & 1 & 0 & 7 & 0 & 0 \\
\hline $\mathbf{4}$ & 6 & 0 & 0 & 1 & 1 \\
\hline $\mathbf{3}$ & 0 & 7 & 0 & 2 & 2 \\
\hline $\mathbf{2}$ & 0 & 0 & 0 & 3 & 3 \\
\hline $\mathbf{1}$ & 0 & 0 & 0 & 1 & 1 \\
\hline $\mathbf{J M L}$ & $\mathbf{7}$ & $\mathbf{7}$ & $\mathbf{7}$ & $\mathbf{7}$ & $\mathbf{7}$ \\
\hline
\end{tabular}

Tabel 09. Rangkuman Hasil Tes Kesegaran Jasmani (TKJI) Mahasiswa Secara Keseluruhan Putra dan Putri

\begin{tabular}{|c|c|c|c|c|c|}
\hline \multirow{2}{*}{$\begin{array}{c}\text { Kategori } \\
\text { Nilai }\end{array}$} & \multicolumn{5}{|c|}{$\begin{array}{c}\text { Item Tes TKJI } \\
\text { (Jumlah Sampel) }\end{array}$} \\
\cline { 2 - 6 } & $\begin{array}{c}\text { Lari } \\
\mathbf{5 0 ~} \mathbf{m} \\
\text { (orang) }\end{array}$ & $\begin{array}{c}\text { Gantung } \\
\text { Siku Tekuk } \\
\text { (orang) }\end{array}$ & $\begin{array}{c}\text { Baring } \\
\text { Duduk } \\
\text { (orang) }\end{array}$ & $\begin{array}{c}\text { Loncat } \\
\text { Tegak } \\
\text { (orang) }\end{array}$ & $\begin{array}{c}\text { Lari } \\
\mathbf{1 0 0 0} \mathbf{~ m} \\
\text { (orang) }\end{array}$ \\
\hline $\mathbf{5}$ & 3 & 3 & 11 & 0 & 0 \\
\hline $\mathbf{4}$ & 8 & 6 & 7 & 3 & 1 \\
\hline $\mathbf{3}$ & 9 & 11 & 2 & 9 & 4 \\
\hline $\mathbf{2}$ & 0 & 0 & 0 & 5 & 11 \\
\hline $\mathbf{1}$ & 0 & 0 & 0 & 3 & 4 \\
\hline JML & $\mathbf{2 0}$ & $\mathbf{2 0}$ & $\mathbf{2 0}$ & $\mathbf{2 0}$ & $\mathbf{2 0}$ \\
\hline
\end{tabular}

Berdasarkan hasil pengukuran seperti yang telah disajikan pada tabel 07, 08, dan 09, maka secara keseluruhan berdasarkan penormaan TKJI, adapun rangkuman hasil kategori kesegaran jasmani mahasiswa PJKR semester $V$ baik putra maupun putri, adalah sebagai berikut.

Tabel 10. Rangkuman Hasil Kategori Kesegaran Jasmani Mahasiswa PJKR

Semester V Baik Putra Maupun Putri

\begin{tabular}{|c|c|c|c|c|}
\hline Angka & $\begin{array}{c}\text { Jumlah Nilai } \\
\text { Lima Item Tes }\end{array}$ & \multicolumn{2}{|c|}{$\begin{array}{c}\text { Klasifikasi Kesegaran } \\
\text { Jasmani }\end{array}$} & $\begin{array}{c}\text { JML } \\
\text { (orang) }\end{array}$ \\
\hline $\mathbf{5}$ & $22-25$ & Baik Sekali & BS & $\mathbf{0}$ \\
\hline $\mathbf{4}$ & $18-21$ & Baik & B & $\mathbf{6}$ \\
\hline $\mathbf{3}$ & $14-17$ & Sedang & S & $\mathbf{1 1}$ \\
\hline $\mathbf{2}$ & $10-13$ & Kurang & K & $\mathbf{3}$ \\
\hline
\end{tabular}


(b) Verifikasi dan Narasi Data (Pendeskripsian Kuantitatif Data)

Berdasarkan paparan data dari hasil pengukuran kesegaran jasamani mahasiswa PJKR semester V, dapat di simpulkan beberapa hal sebagai berikut.

1) Status Kesegaran Jasmani mahasiswa PJKR Semester V yang telah menjalani perkuliahan praktek selama 5 semester (2,5 tahun) memiliki kategori status kesegaran jasmani sebagai berikut; mahasiswa dengan kategori Baik Sekali (BS) berjumlah (0 orang $=0,00 \%$ ), kategori Baik (B) berjumlah (6 orang = $30,00 \%$ ), kategori Sedang (S) berjumlah $(11$ orang = $55,00 \%)$, kategori Kurang $(\mathrm{K})$ berjumlah (3 orang $=15,00 \%$ ), dan kategori Kurang Sekali (KS) berjumlah (0 orang = $0,00 \%$ ), sehingga secara umum rata-rata status kesegaran jasmani berada pada kategori "Sedang" sebesar 55,00\% mahasiswa, berdasarkan nilai norma Tes Kesegaran Jasmani Indonesia (TKJI) yang digunakan adalah nilai norma pada rentang umur $16-19$ tahun.

2) Penggunaan Norma pada rentang umur 16-19 tahun mengindikasikan bahwa hasil tes yang dilakukan pada mahasiswa dengan nilai ratarata kesegaran jasmnai berada pada rentang "Sedang" menggambarkan bahwa secara umum rata-rata status kesegaran jasmani mahasiswa PJKR semester $V$ perlu untuk ditingkatkan ke kategori baik dan baik sekali mengingat umur mahasiswa yang lebih tinggi dari rentang umur norma TKJI 16-19 tahun.

3) Pelaksanaan perkuliahan praktek perlu mendapatkan perhatian lebih dari para dosen PJKR melalui berbagai aktivitas fisik yang cukup dan memadai dalam perkuliahan dengan kemasan berbagai model, formasi, dan strategi pembelajaran yang memungkinkan mahasiswa mendapatkan waktu dan kesempatan dalam perkuliahan untuk dapat meningkatkan status kesegaran jasmani mulai dari semester 1 sampai semester 5, sehingga mahasiswa PJKR benar-benar memiliki tingkat kesegaran jasmani yang baik sebagai salah satu kompetensi dasar yang diperlukan mahasiswa PJKR sebagai calon guru olahraga. 
2. Hasil Tes Keterampilan Kecabangan Sepakbola dan Bolavoli

(a) Pengorganisasian

Data (Reduksi

Data) dan Pengkategorian Data (Display Data)

Tes keterampilan kecabangan olahraga dilakukan secara terpisah sesuai dengan UKM yang diikuti oleh masing-masing mahasiswa menggunakan instrumen masingmasing cabang olahraga, sehingga pengorganisasian data dibuat masing-masing untuk tes Keterampilan Kecabangan Sepakbola dan tes Keterampilan Kecabangan Bolavoli.

Rangkuman hasil tes Keterampilan Kecabangan Sepakbola dan Bolavoli mahasiswa PJKR Semester V, adalah sebagai berikut.

Tabel 11. Rangkuman Hasil Tes Keterampilan Kecabangan Sepakbola Mahasiswa PJKR Semester V

\begin{tabular}{|c|c|c|c|c|c|}
\hline \multirow{3}{*}{$\begin{array}{l}\text { Kategori } \\
\text { Nilai }\end{array}$} & \multicolumn{5}{|c|}{$\begin{array}{l}\text { Item Tes Keterampilan Sepakbola } \\
\text { (Jumlah Sampel) }\end{array}$} \\
\hline & \multirow{2}{*}{$\begin{array}{l}\text { heading } \\
\text { (orang) }\end{array}$} & \multirow{2}{*}{$\begin{array}{l}\text { passing- } \\
\text { stopping } \\
\text { (orang) }\end{array}$} & \multirow{2}{*}{$\begin{array}{c}\text { dribbling } \\
\text { (orang) }\end{array}$} & \multicolumn{2}{|c|}{$\begin{array}{l}\text { shooting } \\
\text { (orang) }\end{array}$} \\
\hline & & & & Nilai & Waktu \\
\hline $61-$ ke atas & 4 & 2 & 2 & 1 & 3 \\
\hline $53-60$ & 4 & 0 & 2 & 6 & 4 \\
\hline $46-52$ & 2 & 2 & 3 & 3 & 3 \\
\hline $37-45$ & 0 & 3 & 3 & 0 & 0 \\
\hline$\leq-36$ & 0 & 3 & 0 & 0 & 0 \\
\hline$J M L$ & 10 & 10 & 10 & 10 & 10 \\
\hline
\end{tabular}

Tabel 12. Rangkuman Kategori Keterampilan Kecabangan Sepakbola Mahasiswa PJKR Semester V

\begin{tabular}{|c|c|l|c|c|}
\hline $\begin{array}{c}\text { Nilai } \\
\text { Keterampilan }\end{array}$ & Skor & \multicolumn{2}{|c|}{$\begin{array}{c}\text { Klasifikasi Keterampilan } \\
\text { Sepakbola }\end{array}$} & $\begin{array}{c}\text { JML } \\
\text { (orang) }\end{array}$ \\
\hline $75-100$ & 5 & Baik & B & $\mathbf{2}$ \\
\hline $58-<75$ & 4 & Cukup & C & $\mathbf{2}$ \\
\hline $42-<58$ & 3 & Sedang & S & $\mathbf{5}$ \\
\hline $25-<42$ & 2 & Kurang & K & $\mathbf{1}$ \\
\hline $0-<25$ & 1 & Kurang Sekali & KS & $\mathbf{0}$ \\
\hline
\end{tabular}

Tabel 13. Rangkuman Hasil Tes Keterampilan Kecabangan Bola Voli Mahasiswa PJKR Semester V Baik Putra Maupun Putri

\begin{tabular}{|c|c|}
\hline $\begin{array}{c}\text { Kategori } \\
\text { Nilai }\end{array}$ & $\begin{array}{c}\text { Item Tes TKJI } \\
\text { (Jumlah Sampel) }\end{array}$ \\
\hline
\end{tabular}




\begin{tabular}{|c|c|c|c|c|}
\hline & $\begin{array}{c}\text { vollying } \\
\text { (orang) }\end{array}$ & $\begin{array}{c}\text { Service } \\
\text { (orang) }\end{array}$ & $\begin{array}{c}\text { passing } \\
\text { (orang) }\end{array}$ & $\begin{array}{c}\text { set-up } \\
\text { (orang) }\end{array}$ \\
\hline $75-100$ & 2 & 2 & 3 & 3 \\
\hline $58-<75$ & 1 & 3 & 1 & 2 \\
\hline $42-<58$ & 5 & 3 & 4 & 4 \\
\hline $25-<42$ & 2 & 2 & 2 & 1 \\
\hline $0-<25$ & 0 & 0 & 0 & 0 \\
\hline JML & $\mathbf{1 0}$ & $\mathbf{1 0}$ & $\mathbf{1 0}$ & $\mathbf{1 0}$ \\
\hline
\end{tabular}

Tabel 14. Rangkuman Kategori Keterampilan Kecabangan Bola Voli Mahasiswa PJKR Semester V Baik Putra Maupun Putri

\begin{tabular}{|c|c|l|c|c|}
\hline $\begin{array}{c}\text { Nilai } \\
\text { Keterampilan }\end{array}$ & Skor & \multicolumn{2}{|c|}{$\begin{array}{c}\text { Klasifikasi Keterampilan } \\
\text { Bola Voli }\end{array}$} & $\begin{array}{c}\text { JML } \\
\text { (orang) }\end{array}$ \\
\hline $75-100$ & 5 & Baik & B & $\mathbf{2}$ \\
\hline $58-<75$ & 4 & Cukup & C & $\mathbf{1}$ \\
\hline $42-<58$ & 3 & Sedang & S & $\mathbf{5}$ \\
\hline $25-<42$ & 2 & Kurang & K & $\mathbf{2}$ \\
\hline $0-<25$ & 1 & Kurang Sekali & KS & $\mathbf{0}$ \\
\hline
\end{tabular}

Tabel 15. Rangkuman Kategori Keterampilan Kecabangan Olahraga Mahasiswa PJKR Semester V Baik Putra Maupun Putri

\begin{tabular}{|c|l|c|c|}
\hline $\begin{array}{c}\text { Skor } \\
\text { Keterampilan }\end{array}$ & \multicolumn{2}{|c|}{$\begin{array}{c}\text { Klasifikasi Keterampilan } \\
\text { Bola Voli }\end{array}$} & $\begin{array}{c}\text { JML } \\
\text { (orang) }\end{array}$ \\
\hline 5 & Baik & B & $\mathbf{4}$ \\
\hline 4 & Cukup & C & $\mathbf{3}$ \\
\hline 3 & Sedang & S & $\mathbf{1 0}$ \\
\hline 2 & Kurang & K & $\mathbf{3}$ \\
\hline 1 & Kurang Sekali & KS & $\mathbf{0}$ \\
\hline
\end{tabular}

(b) Verifikasi dan Narasi Data (Pendeskripsian Kuantitatif Data)

Berdasarkan paparan data dari hasil pengukuran keterampilan kecabangan olahraga mahasiswa PJKR semester V, dapat di simpulkan beberapa hal sebagai berikut.

1) Status Keterampilan Kecabangan mahasiswa PJKR Semester $V$ yang telah menjalani pendampingan dalam kegiatan UKM baik untuk sepakbola mapun bola voli selama 5 semester (2,5 tahun) memiliki kategori status keterampilan sebagai berikut; mahasiswa dengan kategori Baik $(\mathrm{B})$ berjumlah (4 orang = 20,00\%), kategori Cukup (C) berjumlah (3 orang $=15,00 \%$ ), kategori Sedang (S) berjumlah (10 orang $=50,00 \%$ ), kategori Kurang (K) berjumlah (3 orang $=15,00 \%$ ), dan kategori 
2) Kurang Sekali (KS) berjumlah ( 0 orang $=0,00 \%$ ), sehingga secara umum rata-rata status ktatus keterampilan kecabangan mahasiswa berada pada kategori "Sedang" sebesar 50,00\% mahasiswa, berdasarkan nilai norma Tes Keterampilan Sepakbola dan Bola Voli yang digunakan.

3) Hasil yang diporoleh baik cabang sepakbola dan bola voli rata-rata sebagian besar mahasiswa berada pada kategori "SEDANG", hal in mengindikasikan bahwa secara umum status keterampilan mahasiswa PJKR semester $V$ perlu untuk ditingkatkan ke kategori "BAIK" mengingat keterampilan kecabangan olahraga merupakan kompetensi mendasar seluruh mahasiswa PJKR.

4) Pelaksanaan perkuliahan praktek dan pemndampingan UKM keolahragaan sangat perlu mendapatkan perhatian ekstra dari para dosen PJKR melalui berbagai model, formasi, serta strategi pembelajaran dan program latihan yang memungkinkan mahasiswa mendapatkan waktu dan kesempatan dalam perkuliahan dan kegiatan UKM untuk dapat meningkatkan berbagai keterampilan teknik dasar kecabangan olahraga mulai dari semester awal sampai semester-semester akhir 5, sehingga mahasiswa PJKR benar-benar memiliki kemampuan dan keterampilan kecabangan olahraga yang baik sebagai salah satu kompetensi dasar yang diperlukan mahasiswa PJKR sebagai calon guru olahraga.

\section{SIMPULAN DAN SARAN}

Simpulan umum dari hasil penelitian ini, adalah: (1) Status kesegaran jasmani mahasiswa PJKR semester $V$ yang menjalani perkuliahan praktek dan pendampingan pada UKM sepakbola dan bola voli STKIP Citra Bakti selama 5 semester $(2,5$ tahun) rata-rata menunjukan trend pada kategori "SEDANG" dengan jumlah 11 orang (55,00\%). (2) Keterampilan kecabangan olahraga mahasiswa PJKR semester $V$ yang menjalani perkuliahan praktek dan pendampingan pada UKM sepakbola dan bola voli STKIP Citra Bakti selama 5 semester $(2,5$ tahun) rata-rata menunjukan trend pada kategori "SEDANG" dengan jumlah 10 orang $(50,00 \%)$.

Temuan ini menjadi bahan evaluasi real keadaan status kesegaran jasmani dan keterampilan kecabangan olahraga 
mahasiswa PJKR semester V sebagai sampel dari keseluruhan mahasiswa PJKR STKIP Citra Bakti terutama yang berada pada semester 1 dan 3 , sehingga secara umum pelaksanaan keiatan perkuliahan praktek dan pendampingan kegiatan UKM keolahragaan sepakbola dan bola voli harus benar-benar ditingkatkan dengan pendampingan yang lebih serius, displin dan terprogram dengan baik dari para dosen PJKR melalui berbagai aktivitas fisik yang cukup dan memadai dalam perkuliahan dan pendampingan UKM dengan kemasan berbagai model, formasi, serta strategi pembelajaran dan latihan yang memungkinkan mahasiswa mendapatkan waktu dan kesempatan dalam perkuliahan dan kegiatan UKM untuk meningkatkan status kesegaran jasmani dan keterampilan kecabangan olahraga mulai dari semester 1 sampai semester 5 , sebagai salah satu kompetensi dasar yang diperlukan mahasiswa PJKR sebagai calon guru olahraga.

Sebagai bahan evaluasi ke depan, program studi PJKR STKIP Citra Bakti perlu juga melakukan penelitian pengembangan untuk mengembangkan instrument dan norma penilaian kesegaran jasmani dan keterampilan kecabangan olaharaga berdasarkan kearifan, keadaan, dan situasi mahasiswa PJKR STKIP Citra Bakti, menurut kelompok umur mahasiswa untuk dijadikan sebagai salah satu instrument tes masuk mahasiswa baru dan instrument yang layak digunakan oleh prodi, dosen, mahasiswa, mapun peneliti-peneliti lain yang ingin mengukur status kesegaran jasmani dan keterampilan kecabangan olahraga dengan situasi, keadaan, kelompok umur dan cirri-ciri sampel yang sama.

\section{DAFTAR PUSTAKA}

Arikunto, S. (2007), Manajemen Penelitian. Jakarta: PT Rineka Cipta.

Depdikbud (1999). Tes Kesegaran Jasmani Indonesia. Jakarta.

Irianto, D. P. (2004), Pedoman Praktis Berolahraga. Yogyakarta: Andi Offset.

Lutan, R., J. Hartoto., Tomoliyus. (2001), Pendidikan Kebugaran Jasmani (Orientasi Pembinaan Di Sepaanjang Hayat). Jakarta: Depertemen Pendidikan Nasional.

Mukholid. A. (2004), Pendidikan Jasmani dan Olahraga. Jakarta: Yudistira.

Sajoto, M. (1988), Pembinaan Kondisi Fisik Dalam Olahraga. Departemen Pendidikan dan Kebudayaan Direktorat Jenderal Pendidikan Tinggi. Jakarta: Proyek Pengadaan Buku pada Lembaga 


$\begin{array}{lrrr}\text { Pengembangan } & \text { Tenaga } & \begin{array}{c}\text { Winarno, M.E. } \\ \text { Kendidikampilan }\end{array} & \begin{array}{r}\text { (2006), } \\ \text { Olahraga. }\end{array}\end{array}$

Suharjana (2013), Kebugaran Jasmani. Yogyakarta: Jogja Global Media.
Malang: Laboratorium Jurusan

IImu Keolahragaan, Fakultas

IImu Pendidikan Universitas Negeri Malang. 